\title{
SOSIOLOGI PLURALISME DALAM PENDIDIKAN AGAMA KRISTEN UPAYA MEMBANGUN KESATUAN BANGSA
}

\author{
Yonatan Alex Arifianto ${ }^{1}$, Andreas Fernando ${ }^{2}$ \& Reni Triposa ${ }^{3}$ \\ Sekolah Tinggi Teologi Sangkakala, Salatiga ${ }^{1 \& 3}$ \\ Sekolah Tinggi Teologi Ekumene Jakarta ${ }^{2}$ \\ arifianto.alex@sttsangkakala.ac.id ${ }^{1}$, andreasfernando@sttekumene.ac.id ${ }^{2}$, \\ renitriposa@sttsangkakala.ac.id ${ }^{3}$
}

\begin{abstract}
Abstrak
Indonesia pernah mengalami konflik agama dan membawa dampak kemanusiaan yang memprihatinkan. Konflik horizontal tersebut merangsak masuk dalam sendi merusak pilar keutuhan bangsa. Terlebih konflik merusak kerukunan. Oleh karena itu, tujuan penulis mendeskripsikan pluralisme melalui perspektif pendidikan agama Kristen sebagai upaya untuk membawa generasi untuk terus membangun bangsa dan menjaga keutuhannya. Penulisan ini menggunakan metode kualitatif deskritif dengan pendekatan studi literatur yang berhubungan dengan sosiologi pluralisme agama dalam perspektif pendidikan agama Kristen upaya membangun kesatuan Bangsa. Adapun hasil temuan dari penelitian ini. Pertama, sosiologi pluralisme di mulai dari mengenal dan memahami hakikat pluralisme dan memahami seluruh nilai dari kemajemukan. Kedua, seluruh orang percaya terlebih guru dan naradidik melihat dan mengerti bahwa pluralisme dalam konsep pendidikan agama Kristen sangat tidak bertentangan dengan apa yang dilakukan oleh kaum maupun organisasi yang mengusung pluralisme namun perlu ditegaskan bahwa pluralisme dalam kesepakatan hanya untuk menjaga dan membangun keutuhan bangsa. Ketiga, dari dengan tersebut maka Kekristenan, dalam hal ini peran pendidikan agama Kristen, wajib diaktualisasikan dalam hidup bermasyarakat dalam kemajemukan.
\end{abstract}

Kata Kunci: Pluralisme, Kemajemukan, Multikultural Agama, Pendidikan Agama Kristen

\begin{abstract}
Indonesia has experienced religious conflicts and brought about alarming humanitarian impacts. The horizontal conflict has pushed into the joints of destroying the pillars of the nation's integrity. Moreover, conflict destroys harmony, therefore the author's aim was to describe pluralism through the perspective of Christian religious education as an effort to bring generations to continue to build the nation and maintain its integrity. The writing of this article used a descriptive qualitative method with a literature study approach related to the sociology of religious pluralism in the perspective of Christian religious education as an effort to build national unity. The findings of this study are firstly the sociology of pluralism starting from recognizing and understanding the nature of pluralism and understanding all the values of pluralism. Second, all believers, especially teachers and students, see and understand that pluralism in the concept of Christian Religious Education is not contradictory to what is done by people and organizations that promote pluralism, but it needs to be
\end{abstract}


emphasized that pluralism in agreement is only to maintain and build the integrity of the nation. Third, on this basis, Christianity, in this case the role of Christian religious education, must be actualized in social life in pluralism.

\section{Keywords: Pluralism, Multicultural Religion, Christian Religious Education}

\section{Pendahuluan}

Negara Indonesia yang terkenal dengan kepulauan dan keindahan nusantaranya adalah rumah bagi berbagai etnis, ras dan berbagai macam aliran kepercayaan maupun agama yang diikat dalam persatuan di dalamnya. Sikap menghargai keberagaman yang dibangun dalam pondasi kebersamaan membawa nilai dan norma yang mencerminkan toleransi sebagai bangsa yang majemuk dalam hidup bermasyarakat yang plural. Sebab, mengingat negara Indonesia adalah satu negara yang dihuni berbagai komponen sosial dan strata masyarakat sebagai pendukung yang sangat plural. Pluralitas bangsa Indonesia tersebut dapat dilihat dan diketahui dari keberagaman dari ras, suku, bahasa (daerah), budaya dan adat istiadat, serta keyakinannya terhadap Tuhan yang diaktualisasikan dalam ritual agama. Dari potensi positif kebersamaan, keberagaman dan keanekaragaman menjadi sebuah kekayaan, terlebih sebagai sumber daya manusia yang berpotensi untuk menunjang kebersamaan bangsa dan juga dapat dijadikan sebagai modal pembangunan bangsa, di samping kekayaan-kekayaan yang begitu banyak lainnya. ${ }^{1}$

Pluralisme di masyarakat dalam berbagai aspek sudah berlangsung sejak dahulu. Kehidupan bersama dalam ragam budaya dan agama dijalani dengan penuh

\footnotetext{
1 Gunawan Adnan, "Mendefinisikan Ulang Pluralisme Agama Sebagai Sebuah Tantangan Global," Refleksi 13, no. 1 (2011): 35-60.
}

toleransi dan hidup dalam kedamaian. ${ }^{2}$ Namun, keberagaman yang dibangun tersebut bila tidak dirawat dapat menjadi pemicu pertikaian baik konflik secara verbal maupun fisik yang mana hal itu dapat menjadi pematik permasalahan dari nuansa SARA (suku, agama ras, dan antar golongan). Sejatinya konflik bernuansa SARA merupakan salah satu jenis konflik yang tidak gampang untuk diurai dan diselesaikan terlebih pada persoalan berlatar belakang agama, karena fakta di lapangan konflik sosial dalam masyarakat berkenaan dengan kepercayaan mewarnai perjalanan bangsa ini. Sebab salah satu indikator persoalan yang berkaitan dengan problematis dari kemajemukan dalam beragama adalah timbulnya potensi konflik horizontal secara menyeluruh. ${ }^{3}$

Problem sosiologi pluralisme yang terjadi di bangsa Indonesia terjadi ketika sikap masyarakat dalam menghadapi pro dan kontra terhadap perayaan keagamaan seperti hari raya Natal, Tahun baru Imlek atau perayaan agama dengan penganut minoritas. $^{4}$ Bahkan konflik sosiologi pluralisme saat ini sudah merambah dalam dunia maya baik dalam tema

\footnotetext{
2 Aya Susanti, "Relevansi Finalitas Kristus Di Tengah-Tengah Arus Pluralisme Dan Pluralitas Masyarakat Indonesia," Evangelikal: Jurnal Teologi Injili Dan Pembinaan Warga Jemaat 1, no. 1 (2017): 85-102.

${ }^{3}$ Syamsul Arifin, "Kontruksi Wacana Pluralisme Agama Di Indonesia," Jurnal Humanity 5, no. 1 (2009): 11518.

4 Ahmad Khaerurrozikin, "Problem Sosiologis Pluralisme Agama Di Indonesia," Kalimah: Jurnal Studi Agama Dan Pemikiran Islam 13, no. 1 (2015): 93-114.
} 
politik, agama maupun suku, bahkan berlanjut hujat dan fitnah antar golongan. Walaupun demikian, segala konflik yang ada masih dimungkinkan untuk dikelola secara baik demi keutuhan bangsa. ${ }^{5}$ Pertikaian dalam masyarakat majemuk merupakan hal yang tidak dapat dielakkan lagi, namun berkaca dari peristiwa yang lalu, pertikaian bersumber dari isu agama di sejumlah daerah menimbulkan kerugian yang sangat mahal. ${ }^{6}$ Sebut saja kerusuhan yang meledak di beberapa kota Ambon dan Poso yang mengakibatkan banyaknya korban jiwa serta material yang hancur sia-sia. Konflik massif yang melibatkan agama dan suku menghancurkan simbol dan arti toleransi. Dan koflik-konflik tersebut tampaknya bukan akhir dari pertikaian SARA. Fakta dilapangan juga menunjukan adanya konflik horizontal yang terjadi terus menerus dalam masyarakat sosial yang mengataskan namakan SARA, terus bermunculan baik dalam skala kecil, dan selanjutnya melebar keberbagai daerah dalam bentuk persoalan izin mendirikan rumah ibadah ataupun persoalan ibadah itu sendiri.

Bahkan di kota Bekasi, kota Denpasar, Bogor, Kupang, Depok, Kota Makassar, serta kota Padang, dan sejumlah daerah lainnya menunjukkan peningkatan signifikan dari konflik skala kecil yang berlatar belakang soal pendirian rumah ibadah di sepuluh tahun terakhir ini. Yang mana dalam

\footnotetext{
5 Saihu Saihu, "Pendidikan Pluralisme Agama: Kajian Tentang Integrasi Budaya Dan Agama Dalam Menyelesaikan Konflik Sosial Kontemporer," Jurnal Indo-Islamika 9, no. 1 (2019): 67-90.

6 Mahathir Muhammad Iqbal, "Pendidikan Multikultural Interreligius: Upaya Menyemai Perdamaian Dalam Heterogenitas Agama Perspektif Indonesia," SOSIO-DIDAKTIKA: Social Science Education Journal 1, no. 1 (2014): 89-98.
}

masyarakat modern saat ini masih begitu responsif bahkan sensitif terhadap hal-hal yang dianggap menyinggung iman atau akidah dari keyakinannya, terutama dalam pendirian rumah ibadah yang tidak seiman maupun dalam penyiaran agama lain menjadi ancaman serius bagi kelompok tertentu. Hal itu menandakan adanya elevasi potensi yang tersembunyi dari pertikaian, menciptakan bom waktu yang dapat meledak kapan pun. Dimana hal itu dapat merusak toleransi dan kebhinekaan mengingat konflik bernuansa keagamaan di Indonesia masih cukup tinggi. $^{7}$ Konflik tersebut merupakan ancaman dari pandangan sentrisme penafsiran ajaran agama yang berpotensi menggesek kebersamaan komunitas masyarakat majemuk dan multikultural. Sebab, terkadang interpretasi terhadap kebenaran yang diyakini mutlak dalam penafsiran agama sering menggunakan standar ganda, kebenaran yang dimunculkan adalah kebenaran yang absolut dan berotoritas penuh bagi penganut komunitas agama sendiri, sedangkan untuk penganut agama lain dianggap jauh dari kebenaran yang hakiki, ${ }^{8}$ maka hal tersebut berdampak negatif terhadap keyakinan yang merasa benar. Sehingga orang dengan mudah terbawa arus dalam tindak dan prilaku radikalisme dengan mempolitisasi agama sebagai sumber radikalisme terbuka. ${ }^{9}$ Apalagi, dengan adanya klaim kebenaran (truth claim) dan sifat misioner yang

\footnotetext{
${ }^{7}$ Iqbal.

8 Catur Widiat Moko, "Pluralisme Agama Menurut Nurcholis Madjid (1939-2005) Dalam Konteks Keindonesiaan," Medina-Te: Jurnal Studi Islam 13, no. 1 (2017): 61-78, https://doi.org/10.19109/medinate.v13i1.1542.

9 Angga Natalia, "Faktor-Faktor Penyebab Radikalisme Dalam Beragama (Kajian Sosiologi Terhadap Pluralisme Agama Di Indonesia)," AlAdyan: Jurnal Studi Lintas Agama 11, no. 1 (2016): 36-56.
} 
tertanam pada penganut agama, maka perbedaan dapat menjadi pangkal konflik yang tidak pernah terselesaikan bahkan menjadi pemicu persoalan demi persoalan yang lainnya sehingga menambah daftar panjang konflik yang terjadi dibumi pertiwi ini. Sehingga, dalam pluralitas ataupun perbedaan, masyarakat menjadi amat rentan dengan konflik-konflik dengan nuansa kesakralan keyakinan beragama dalam bungkusan nama agama. ${ }^{10}$ Sejatinya setiap penganut agama berkeyakinan bahwa agama yang dipeluknya memiliki konsep dan cara tersendiri untuk terhubung dengan penciptanya, ${ }^{11}$ yang tidak bisa dipaksakan harus mengikuti mayoritas maupun masyarakat mengaku sebagai komunitas yang superioritas.

Sejatinya agama dan masyarakat adalah dua hal yang tidak terpisahkan dan secara resiprokal memberi pengaruh satu sama lain. Agama menjadi acuan dalam bangunan value dan moral yang diterima secara universal serta berperan membentuk sikap dan perilaku manusia dalam menjalani dan menghadapi proses hidup. Sementara itu, masyarakat merupakan komunitas di mana individu dilatih dan membangun diri dalam agamanya. Hal itu dapat dikatakan bahwa sejatinya sebagai makhluk sosial, seseorang tidak dapat menjadi manusia sepenuhnya tanpa sentuhan agama. ${ }^{12}$ Oleh karena itu, hubungan yang tercipta antara agama dan manusia sosial merupakan sebuah hubungan sepenuhnya dalam totalitas. Walaupun pada hakikatnya

10 Fatonah Dzakie, "Meluruskan Pemahaman Pluralisme Dan Pluralisme Agama Di Indonesia," Al-Adyan: Jurnal Studi Lintas Agama 9, no. 1 (2014): 79-94.

${ }^{11}$ Frithjof Schuon, Roots of The Human Condition (Paris, Prancis: World Wisdom Book, 1990), 12.

12 Moko, "Pluralisme Agama Menurut Nurcholis Madjid (1939-2005) Dalam Konteks Keindonesiaan." peran keyakinan atau agama tidak bisa dipisahkan dari kehidupan makluk sosial tersebut. Tetapi, faktanya bahwa agama atau keyakinan manusia dibumi ini terhadap Tuhan, atau percaya akan adanya pencipta oleh manusia bukan hanya satu agama atau kepercayaan saja, melainkan ada begitu banyak. Maka perbedaan keyakinan ini sangat dimungkinkan dan tidak terelakkan berdampak terhadap timbulnya konflik akibat klaim kebenaran sepihak dari masing-masing penganut agama tertentu. Secara normatif semua agama dalam ajaran atau doktrin setuju memberikan ruang dalam mengajarkan hidup penuh kedamaian, persaudaraan, saling menghormati dan tentunya tentang keselamatan pemeluknya. Akan tetapi, pada implementasi di lapangan, muncul kesenjangan ketika ajaran tersebut dilaksanakan oleh para pemeluknya secara ekslusif sesuai penafsiran dan kebutuhan. Maka seringkali muncul persoalan dari kesenjangan tersebut bahkan dapat saja menggerakkan tindakan kontraproduktif bagi kemajemukan yang dapat berlanjut pada tindak kekerasan dan berujung kepada radikalisme bagi sesama dan bagi negara. ${ }^{13}$

Sejatinya toleransi dan harmoni antar pemeluk agama yang berbeda adalah kebutuhan mendasar dan mendesak bagi terwujudnya stabilitas keamanan dan ketertiban negara dalam masyarakat. ${ }^{14}$ untuk itu dibutuhkan kecerdasan masyarakat dalam bersikap terhadap perbedaan dalam mengupayakan

\footnotetext{
${ }^{13}$ Natalia, "Faktor-Faktor Penyebab Radikalisme Dalam Beragama (Kajian Sosiologi Terhadap Pluralisme Agama Di Indonesia)."

${ }^{14}$ Enggar Objantoro, "Pluralisme Agama-Agama: Tantangan Bagi Teologi Kristen," Jurnal Simpson: Jurnal Teologi Dan Pendidikan Agama Kristen 1, no. 1 (2014): 61-80, https://journal.sttsimpson.ac.id/index.php/Js/articl e/view/6.
} 
dan mewujudkannya. Pendidikan menjadi sarana bagi pendewasaan sikap manusia untuk memperluas wawasan kebersamaan sehingga mampu mengembangkan diri menjadi manusia yang kompetitif. Maka akan terbangun masyarakat yang minim kesenjangan sebagai pemicu pertentangan atau pertikaian. Pendidikan dalam konteks ini merupakan upaya membangun manusia dalam menanamkan nilai dan moral yang berasal dari ajaran agama. ${ }^{15}$ Pendidikan sebagai sebuah proses membawa perubahan kedalam dasar humanisasi yang menitikberatkan pada pembentukan sikap dan prilaku individu diharapkan mampu mengupayakan manusia sebagai makhluk sosial dengan kemandirian moral, kepekaan emosional, serta mempunyai kedaulatan budaya. Dari hasil ini maka masyarakat majemuk diharapkan memiliki kemampuan untuk mengelola setiap persoalan yang berkaitan dengan masyarakat horizontal bahkan dapat meredam konflik, terlebih dapat bersikap menghargai kemajemukan, sebagai dasar bermasyarakat serta dapat memahami keperbedaan. Tentunya kemajemukan tersebut dapat menemukan jalan keluar bagi setiap permasalahan yang terjadi. ${ }^{16}$

Implementasi pendidikan agama yang terintregasi dengan nilai kerukunan yang terbangun dari adat dan kebiasaan masyarakat pada gilirannya menghasilkan model pendidikan agama yang dapat melahirkan peserta didik yang takut akan Tuhan atau hidup dalam kesalehan secara individual dan juga membentuk karakter yang memiliki integritas dalam menjunjung nilai-nilai kemanusiaan dan keberagaman manusia

15 Saihu, "Pendidikan Pluralisme Agama: Kajian Tentang Integrasi Budaya Dan Agama Dalam Menyelesaikan Konflik Sosial Kontemporer." ${ }^{16}$ Saihu. di sekitarnya secara terbuka. ${ }^{17}$ Dari persoalan sosial masyarakat yang sering terbentur dengan konflik horizontal baik berdasarkan agama maupun lainnya, berdampak pada disintegrasi bangsa dan perpecahan dalam kesatuan membangun keutuhan bangsa. Untuk itu penulis mendeskripsikan tujuan penelitian ini menekankan sosiologi pluralisme dalam bingkai pendidikan agama Kristen yang mana dalam segala hal diharapkan orang percaya dapat membangun keutuhan dan menjaga bangsa dari perpecahan.

Berkaitan dengan topik pluralisme agama dalam perseptif pendidikan agama Kristen upaya membangun kesatuan Bangsa, penelitian oleh Muhandis Azzuhri membuat kajian tentang multikulturalisme dan pluralisme dalam upaya menguniversalkan pendidikan agama dalam konteks Keindonesiaan. ${ }^{18}$ Kesimpulan dari penelitian tersebut menggambarkan nilai dan konsep multikulturalisme dan pluralisme yang seharusnya bukan menjadi bagian persoalan besar lagi dibangsa ini. Namun sejatinya dapat diimplementasikan dalam lingkup pendidikan di Indonesia lewat mata pelajaran ataupun mata kuliah pembelajaran agama dengan prasyarat yang wajib terpenuhi, ialah komitmen yang kuat selaku penganut agama dan juga tiap pribadi sebagai partisipan didik. Begitu pula dengan Fransiskus Irwan Widjaja dalam penelitian yang bertemakan mengenai tantangan bermisi dalam pluralitas yang mengkonsepsi pendidikan agama Kristen di kemajemukan masyarakat, memberikan kesimpulan bahwa penginjilan yang dapat

\footnotetext{
${ }^{17}$ Saihu.

${ }^{18}$ Muhdanis Azzuhri, "Konsep Multikulturalisme Dan Pluralisme Dalam Pendidikan Agama (Upaya Menguniversalkan Pendidikan Agama Dalam Ranah Keindonesiaan)," in Forum Tarbiyah, vol. 10, 2012, 13-29.
} 
membawa perubahan harus memiliki fokus yang kuat berfokus kepada strategi misi dengan didasari konsep pendidikan agama Kristen. ${ }^{19}$ Begitu juga dengan Stanley R. Rambitan dalam penelitian yang mengkaji persoalan bagaimana pandangan Kristen mengenai pluralitas dan implikasi dalam pengajaran agama Kristen yang berkesimpulan bahwa pendidikan dan proses berteologi adalah dua hal yang sinergik. $^{20}$ Pemahaman teologis dan sikap yang tumbuh kemudian diaktualisasikan oleh umat Kristen memberikan kaitan dan dampak kepada setiap upaya pembelajaran nilai dan ajaran kristen kepada para generasi selanjutnya.

Pada ketiga penelitian terkait pluralitas tersebut menyisakan persoalan yang belum dikaji yaitu mengenai pluralisme agama dalam perspektif pendidikan agama Kristen upaya membangun kesatuan Bangsa sebagai mayor dalam tulisan ini. Konsep pendidikan agama Kristen mendasari cara dan prilaku seseorang dalam melihat pluralisme yang berujung pada tataran sebagai impak bagi sesama lewat membangun kesatuan bangsa menjadi prioritas dalam artikel ini.

\section{Metode}

Artikel ini disusun dengan menggunakan metode penelitian kajian literatur melalui pendekatan kualitatif

19 Fransiskus Irwan Widjaja, "Pluralitas Dan Tantangan Misi: Kerangka Konseptual Untuk Pendidikan Agama Kristen Dalam Masyarakat Majemuk," Regula Fidei 4, no. 1 (2019), https://doi.org/10.33541/jrfvol1 iss1pp115.

${ }^{20}$ Stanley R. Rambitan, "Pluralitas Agama Dalam Pendangan Kristen Dan Implikasinya Bagi Pengajaran Pak," Jurnal Shanan 1, no. 1 (2017): 93-108,

https://doi.org/10.33541/shanan.v1i1.1473. deskriptif, ${ }^{21}$ penulis mengkaji sumber pustaka yang memuat persoalan terkait sosiologi pluralisme agama dalam perseptif pendidikan agama Kristen upaya membangun kesatuan bangsa. Dalam mendapatkan makna dari pendidikan agama Kristen, penulis menggunakan teks-teks paralel Alkitab yang mendukung konsep pluralisme, yang merupakan bentuk pemahaman dan sikap keteladanan bagi orang percaya masa kini untuk mewujudkan kedamaian bersama sebagai bagian dari membangun keutuhan dan kesatuan bangsa. Penulis juga memaparkan deskripsi pluralisme sebagai kajian analitis bertalian dengan keadaan masyarakat luas secara heterogen dalam pluralisme Indonesia

\section{Pembahasan}

\section{A. Hakikat Pluralisme dan Sikap Kemajemukan}

Pluralisme dalam hidup keberagamaan merupakan tuntutan realitas tidak dapat ditampik yang secara tidak langsung mengarahkan tiap-tiap umat beragama harus berperan yang baik dan positif dalam menciptakan harmoni dalam hidup bersama. Walaupun dalam bermasyarakat ada perbedaan, namun sejatinya orang percaya diwajibkan saling mengerti dan menerima. Tetapi realitanya bahwa ada kelompok masyarakat menciptakan konflik-konflik yang didasari dengan berbagai motif, telah memberikan dampak sangat negatif terhadap situasi dimana masyarakat hidup berdampingan. Konflik tersebut memperlebar ketidak harmonisan sehingga memperluas jurang pemisah sosial, dapat melunturkan hubungan

21 Umrati dan Hengki Wijaya, Analisis Data Kualitatif Teori Konsep Dalam Penelitian Pendidikan (Sulawesi Selatan: Sekolah Tinggi Theologia Jaffray, 2020), 12. 
persaudaraan, bahkan sampai meninggalkan dampak psikologis yang sulit untuk dihilangkan, terlebih meluluhlantahkan modal kehidupan bersosial yang telah ada. ${ }^{22}$ Seperti kejadian Konflik agama di Poso dan Ambon, bahkan adanya doktrin yang salah ditafsir yang berdampak pada radikalisme dan terorisme. Bahkan didalam masyarakat yang penuh toleransi dibenturkan oleh konflik agama dalam pendirian rumah ibadah atau gereja GKI Yasmin di kota bogor. $^{23}$

Untuk itu pluralisme menjadi prasyarat yang mendasar bagi terciptanya kondisi yang nyaman serta hidup kebersamaan dan damai dalam kemajemukan bermasyarakat. ${ }^{24}$ Pluralisme agama merupakan suatu konsep yang mengandung arti dan nilai yang luas, yang bertalian dengan sikap, value dan moral dalam menerima perbedaan keyakinan, dan diterapkan dalam: pertama pluralisme digunakan sebagai pandangan dan sikap dunia yang mempermaklumkan bahwa agama tertentu yang dianut seseorang tidak dapat menjadi sumber mutlak kebenaran yang eksklusif, dan berimplikasi bahwa dapat ditemukan juga kebaikan dan kebenaran pada konsep-konsep agama lain, sekurang-kurangnya, suatu kebenaran dan nilai-nilai yang benar. ${ }^{25}$ Kedua, sebagai penerimaan terhadap konsep bahwa dari berbagai aliran agama yang beragam dengan klaim kebenaran masing-masing

22 Arafat Noer, "Pluralisme Agama Dalam Konteks Keislaman Di Indonesia," Religi: Jurnal Studi Agama-Agama 15, no. 1 (2019): 51-75.

23 Firdaus M Yunus, "Konflik Agama Di Indonesia Problem Dan Solusi Pemecahannya," Substantia: Jurnal Ilmu-Ilmu Ushuluddin 16, no. 2 (2014): 217-28, http://substantiajurnal.org.

24 Objantoro, "Pluralisme Agama-Agama: Tantangan Bagi Teologi Kristen."

25 Dzakie, "Meluruskan Pemahaman Pluralisme Dan Pluralisme Agama Di Indonesia." yang bersifat eksklusif dan bernilai mutlak. Pandangan ini secara normatif memberi penekanan adanya kesamaan nilai pada tiap agama. ${ }^{26}$ Oleh karena itu, kenyataan keberagaman atau perbedaan yang terdapat pada satu bangsa itu seyogyanya dapat selalu ditanggapi secara positif dan optimis. Seluruh komponen komunitas dan lapisan masyarakat harus dapat menerima hal ini sebagai realitas dalam hidup berbangsa dan bernegara. ${ }^{27}$

Konteks pluralisme yang disadari oleh tiap-tiap agama dan penganutnya menempatkan nilai kesetaraan dalam perbedaan dan memberi ruang sebagai peluang untuk melakukan kerjasama. Sebab, bila ruang perbedaan tidak diisi dengan kerjasama, maka akan menyisakan kesempatan yang berkaitan dengan pertentangan dan perselisihan horizontal secara lokal, baik yang melibatkan kelompok dan keyakinan, bahkan hingga memicu pertikaian serta ketidakharmonisan sosial yang akan terus menyebar dalam masyarakat majemuk di bangsa ini. ${ }^{28}$ Seperti kejadian yang terjadi akhir-akhir ini adanya penistaan agama oleh rohaniawan baik dari pihak Muslim maupun Kristen.

Untuk itu yang harus dilakukan oleh segenap pemeluk beragama untuk berusaha memahami secara jujur dan terbuka penyebab konflik kepentingan dan konfrontasi di antara mereka. ${ }^{29}$ Maka

\footnotetext{
${ }^{26}$ Dzakie.

Hendri Masduki, "Pluralisme Dan Multikulturalisme Dalam Perspektif Kerukunan Antar Umat Beragama (Telaah Dan Urgensinya Dalam Sistem Berbangsa Dan Bernegara)," DIMENSI-Journal of Sociology 9, no. 1 (2016): 15-23.

${ }^{28}$ Yunus, "Konflik Agama Di Indonesia Problem Dan Solusi Pemecahannya."

${ }^{29}$ Albertus Patty, "Paradigma Teologia Kristen Terhadap Pluralisme," Situs Komunitas Jemaat GKI Pondok Indah - Jakarta, 2007,
} 
akan ada hidup tenang dan damai sejahtera yang juga memberi dampak dalam menjunjung tinggi nilai-nilai toleransi. ${ }^{30}$ Terlebih pluralisme di negara Indonesia sudah menjadi sesuatu yang wajar dan harus diterima sebagai fakta yang tidak bisa ditolak. Menolak fakta pluralisme sebetulnya merupakan pertanda dari sikap yang kurang bijaksana dalam nilai kerukunan sesama anak bangsa, karena menolak kemajemukan berarti menolak esensi dari manusia itu sendiri. $^{31}$ Sebab tujuan dari sikap dan pandangan yang dicetuskan tersebut dapat membina masyarakat hidup dalam damai serta bertoleransi dalam keberagaman. ${ }^{32}$

Karena pemicu dari sumber problem dan perpecahan antar umat beragama terjadi disebabkan tidak adanya kerukunan yang merujuk saling pengertian, saling menghormati antar pemeluk beragama berbeda, sehingga mau tidak mau solusi dari mencegah konflik diperlukan formula pluralisme agama, ${ }^{33}$ yang terjadi hampir secara bersamaan dalam sepuluh tahun terakhir ini. Sikap kerukunan dapat terwujud dengan mengakui eksistensi keyakinan dan hak beragama dari masing-masing pemeluk dan tidak beropini bahwa hanya ajaran dan nilai agamanya yang paling benar. $^{34}$ Hal ini dirancang supaya kerukunan terjadi dan membawa dampak bagi kemajuan dan keutuhan bangsa. Sehingga dari kerukunan tersebut

https://gkipi.org/paradigma-teologia-kristenterhadap-pluralisme-agama/.

${ }^{30}$ Khaerurrozikin, "Problem Sosiologis Pluralisme Agama Di Indonesia."

31 Raja Oloan Tumanggor, "Misi Dalam Masyarakat Majemuk,” 2021, 40.

32 Yushak Soesilo, "Gereja Dan Pluralisme Di Indonesia," n.d.

33 Yusuf Umma, "Menangani Masalah Konflik Agama," Jurnal Jaffray 1, no. 1 (2005): 16-24.

${ }^{34}$ M. Legenhausen, Pluralitas Dan Pluralisme Agama (Jakarta: Shadra Press, 2010), 37-38. membentuk pola pikir bahwa pluralisme merupakan nilai dari prinsip komunitas yang berbeda namun dapat menjalin hidup berdampingan dengan damai dalam komunitas masyarakat heterogen dibangsa ini. $^{35}$

Pluralisme menjadi kesadaran baru yang diaktualisasikan dalam menghormati perbedaan dengan sebuah paradigma mengenai kesetaraan secara universal yang dimiliki atau ada pada tiap-tiap agama dan keyakinan di dunia. Implikasinya, dalam mewujudkan kerukunan dalam beragamnya keyakinan, maka tidak ada satu pun agama atau penganutnya yang menganggap paling benar dan baik dari yang lainnya, ${ }^{36}$ dimana pernyataan tersebut di deklarasikan di komunitas yang dapat memicu disintegrasi. Namun sebagai tanggung jawab orang percaya terhadap panggilan keselamatan maka secara inklusif harus diterapkan dalam kerohanian orang percaya secara pribadi. sedangkan dalam kaitannya terhadap persatuan tetap menjunjung tinggi kerukunan dan perbedaan sebagai bagian dari membangun keutuhan dan kemajuan ibu pertiwi. Walaupun dalam ranah keimanan konsep keselamatan menjadi prioritas penting lebih dari nilai pluralisme itu sendiri. Pluralisme yang dibangun dalam sikap kekristenan adalah pluralisme yang menjunjung kerukunan sebagai nilai utama. Hal itu disebabkan bahwa sebagai bagian dari anak bangsa diharapkan dapat menjaga dan membangun bangsa Indonesia. Tetapi

\footnotetext{
35 Harda Armayanto, "Problem Pluralisme Agama," Tsaqafah 10, no. 2 (2014): 325-40.

${ }^{36}$ Endry Setiawan, "Apologetika Prasuposisional Triperspektivalisme John M. Frame Dan Aplikasinya Terhadap Pemikiran Kristen Pluralis Tentang Pluralisme Agama Di Indonesia," Veritas: Jurnal Teologi Dan Pelayanan 17, no. 1 (2018): 61-80.
} 
sikap akan nilai keselamatan tidak dapat ditawar bahwa keselamatan hakiki tetap di imani menjadi keselamatan yang absolut. Hal itu mengacu kepada Kisah Para Rasul 4:12, yang dengan tegas menyatakan kebenarannya. Dalam Iman Kristen perihal keselamatan adalah mutlak dan ekslusif melalui pribadi Sang Juruselamat yaitu Yesus Kristus, ini merupakan hal mutlak dan tak tergantikan. Dengan demikian pribadi Yesus Kristus dalam Alkitab adalah jalan keselamatan satu-satunya, dan tidak ada pilihan lain sebagai jalan bagi keselamatan. Sebab keselamatan tersebut berpusat pada janji Allah. ${ }^{37}$ Walaupun iman kepercayaan yang diyakini berbeda dengan konsep agama lain, namun sebagai orang percaya dimanapun berada baik dalam ranah pendidikan ataupun dalam kehidupan sosial di tengah masyarakat diharapkan tetap menjaga kerukunan dan terlebih mendukung pluralism sebagai kesepakatan bersama. Karena Orang percaya diwajibkan membangun iman teologi dan sosialnya yang berjalan bersamaan berada di antara orang banyak dalam hidup kebersamaan yang multikultural. ${ }^{38}$

\section{B. Pluralisme dalam Konsep Pendidikan Agama Kristen}

Adanya keberagaman agama dan kebudayaan di bangsa Indonesia acapkali menimbulkan konflik horizontal antara para penganut atau komunitas keagamaan.

\footnotetext{
37 Yunardi Kristian Zega, “Jaminan Keselamatan Dalam Injil Yohanes 10: 28-29 Dan Implikasinya Bagi Pengajar Pendidikan Agama Kristen," Jurnal Ilmiah Religiosity Entity Humanity (JIREH) 3, no. 1 (2021): 76-87.

38 Elia Tambunan, "Pendidikan Progresif Dan Kaum Urban: Mencari Wajah Baru Kontribusi Sosial," EDULEAD: Journal of Christian Education end Leadership 1, no. 1 (2020): 56-76, https://doi.org/10.47530/edulead.v1i1.27.
}

Hal itu menunjukkan bahwa keyakinan yang diharapkan dapat membawa kedamaian gagal. Dikatakan demikian karena fakta menunjukkan bahwa agama tidak lagi dapat membawa kebaikan dalam konteks hidup berdampingan dengan yang lain. Agama yang semestinya menjadi rahmat bagi seluruh umat manusia kurang ampuh dalam menunjukkan pengaruh dan peran signifikan dalam merajut kerukunan umat manusia. Berbagai macam agama dan etnis di bangsa Indonesia yang semestinya memberi kesan kerukunan dan warna indah bagi kebersamaan namun, pada kenyataannya banyak menimbulkan salah paham. Hal ini dimungkinkan akibat adanya kepentingan pribadi atau kelompok tertentu dalam membangun pemahaman dan pemaknaan nilai-nilai kehidupan beragama. Hal-hal negatif yang ditimbulkan oleh ajaran atau paham ekslusif pada satu agama dapat disebabkan oleh faktor kepentingan di luar keagamaan itu sendiri. Tidak sedikit ajaran agama terkontaminasi oleh kepentingan lain seperti politik, kepentingan ekonomi ataupu juga kepentingan budaya yang diusung oleh pihak tertentu yang memiliki akses. ${ }^{39}$ Oleh karena itu pentingnya peran pendidikan dalam mengedukasi orang percaya untuk dapat membawa sikap dan prilaku bagi masyarakat multikultural diharapkan sesuai dengan tuntutan value Alkitabiah. Tidak dapat dipungkiri bahwa pengakuan akan keanekaragaman agama menjadi konsekuensi dari diterimanya prinsip manusia sebagai gambar Allah. Berdasar pemahaman ini maka penekanan kesetaraan dan kebernilaian manusia, apapun agamanya, di hadapan Allah Sang Pencipta haruslah dinyatakan dalam

\footnotetext{
39 Moko, "Pluralisme Agama Menurut Nurcholis Madjid (1939-2005) Dalam Konteks Keindonesiaan."
} 
pendidikan agama Kristen. Implikasinya ialah bahwa setiap manusia melalui agama memiliki hak dalam berhubungan dengan Allah sepenuhnya dan tanpa dapat dipengaruhi orang atau agama lain. ${ }^{40}$ Untuk itu, pendidikan agama Kristen penting dalam mengajarkan bahwa keberadaan agama yang hadir sejatinya dibentuk bagi kemuliaan Allah. Maka dari itu, tiap-tiap orang percaya atau orang Kristen terutama para pendidik atau guru agama dapat mengaktualisasikan nilai dan sikap pengertian yang sejalan dengan kebenaran. Terlebih melaksanakan hidup berdampingan penuh sikap toleransi dan juga memiliki standart nilai kehidupan berkarakter serta iman yang matang, yang mampu menerima sesama, menghargai sesama, dan memandang keberagaman yang diciptakan oleh Tuhan itu sebagai bentuk anugerah dan kebaikan Allah yang harus disyukuri dengan jalan memelihara dan melestarikannya terus menerus hal yang membawa kepada kebaikan bersama. $^{41}$

Sehingga hal itu dapat memberikan keteladanan bagi jemaat maupun kepada para naradidik yang secara sengaja membawa perubahan prilaku yang berdampak bagi keutuhan bangsa. Pendidikan agama Kristen yang merupakan upaya dalam mendidik semua orang percaya dari segala usia di lingkup keluarga, gereja, sekolah, dan masyarakat, dilakukan secara sistematis dan

40 Desi Sianipar, "Pluralisme Agama Menurut Abraham Kuyper Dan Kontribusinya Bagi Pengembangan Pendidikan Agama Kristen," Jurnal Shanan Vol.3, no. No.1 (2019): 105-7, http://ejournal.uki.ac.id/index.php/shan/article/vie w/1576.

${ }^{41}$ Y K Zega, "Radikalisme Agama Dalam Perspektif Alkitab Dan Implikasinya Bagi Pendidikan Agama Kristen," Jurnal Shanan 4, no. $1 \quad$ (2020): 1-20, http://ejournal.uki.ac.id/index.php/shan/article/vie w/1765. berkesinambungan dengan tujuan untuk mendewasakan iman dan kerohanian dalam mengiring Tuhan dikehidupan yang nyata dalam masyarakat serta dapat membangun sikap dan prilaku dan karakter mereka menurut nilai-nilai Kristen terutama nilai Alkitabiah. ${ }^{42}$ Sebab sejatinya peran lembaga pendidikan khususnya pendidikan agama diharapkan mampu menjadi sarana strategis dalam upaya internalisasi nilai-nilai pluralisme agama dalam rangka kerukunan bagi masyarakat yang majemuk. ${ }^{43}$

Oleh sebab itu adanya pemahaman terhadap pentingnya kerukunan secara universal, dan penerimaan terhadap perbedaan serta sikap yang tepat terhadap multikultural dalam hal ini pluralis dapat memupuk kebersamaan membangun bangsa dan juga dapat menghadapi segala hal persoalan di masyarakat majemuk atau plural. Dengan tujuan yang jelas untuk menghadirkan damai dan kenyamanan dalam proses perjalanan kehidupan dari latar belakang yang berbeda. ${ }^{44}$ Sehingga nilai dan prinsip pluralitas tidak diasumsikan sebagai penghalang bagi kesatuan, tetapi dipersepsikan sebagai modal dalam memperkaya dan saling melengkapi sesama anak bangsa menuju cita-cita luhur bangsa dan ajaran agama yang membawa kebaikan kepada sesama.

Keragaman dalam kelompok masyarakat dipandang sebagai nilai untuk mempersatukan persekutuan orang percaya terlebih dahulu. Seperti yang

\footnotetext{
${ }^{42}$ Sianipar, "Pluralisme Agama Menurut Abraham Kuyper Dan Kontribusinya Bagi Pengembangan Pendidikan Agama Kristen."

${ }^{43}$ Djunawir Syafar, "Pluralisme Agama Dalam Pendidikan (Potret Toleransi Beda Agama Di Sd Negeri 46 Hulontalangi Kota Gorontalo)," Jurnal Kajian Islam Interdisipliner 2, no. 2 (2017): 99115.

${ }^{44}$ Rambitan, "Pluralitas Agama Dalam Pendangan Kristen Dan Implikasinya Bagi Pengajaran Pak.”
} 
dinyatakan Paulus bahwa seperti tubuh itu mempunyai fungsi dalam hal saling melayani, yang diarahkan oleh kepala dalam hal sesama ialah Kristus. Ia sendiri yang mengikat anggota-anggota tubuh itu menjadi satu kesatuan. ${ }^{45}$ Sejalan dengan itu Tuhan Yesus menyatakan perintah pada orang percaya agar mengasihi sesama manusia tanpa mempersoalkan perbedaan keturunan, bangsa, keyakinan, adat, dan strata sosial. Dalam Lukas 6: 27-36, Tuhan Yesus malahan mengajarkan untuk mengasihi musuh, ataupun mengasihi orang yang membenci dengan melakukan apa yang baik. Bahkan dalam Matius 5:44 Yesus memberi tambahan agar orang percaya selain mengasihi orang yang memusuhi juga mengharapkan yang baik melalui doa meski dianiaya. Gambaran kasih kepada sesama dinyatakan Yesus dalam kisah orang Samaria yang murah hati (Lukas 10:25-37). Pada kisah yang disampaikanNya tampak jelas sikap Yesus dalam memandang perbedaan, baik dalam hal suku, rasas maupun agama yang tidak menjadikannya sebagai penghalang untuk menyatakan cinta kasih dan damai sejahtera kepada sesama. Sehingga Yesus adalah tokoh pluralisme sejati. ${ }^{46}$ Hal itu juga dinyatakan Yesus bahwa Tuhan Dalam Matius 5:45 menyatakan bahwa Allah Bapa mememberikan kehidupan kepada manusia tanpa memandang bulu dan berdasar perbuatannya dan perlakuanNya tidak dibedakan karena latar belakang kebenaran. Di sini Tuhan Yesus mengajar orang percaya untuk

\footnotetext{
${ }^{45}$ Nieke Kristiana Atmadja Hadinoto, Dialog Dan Edukasi Keluarga Kristen Dalam Masyarakat Indonesia (Jakarta: BPK Gunung Mulia, 1999), 267.

${ }^{46}$ Talizaro Tafonao, Pendidikan Agama Kristen Dalam Masyarakat Majemuk (Yogyakarta: illumiNation Publishing, 2019), 120.
}

menghormati dan menghargai manusia yang diciptakan Tuhan tanpa syarat.

Demikian juga dengan Rasul Paulus membawa kabar baik dalam memperkenalkan pribadi Tuhan dengan penuh hikmat, tidak menebar kebencian atau penghinaan kepada penganut kepercayaan yang bertentangan dengan imannya. Dalam Kisah Rasul 17;23, tercatat mengenai pendekatan Paulus dalam memberitakan injil di kota Athena dengan menggunakan latar belakang pemahaman dan budaya masyarakat. Paulus menunjukkan betapa bijak dan berakal budi ia, mempresentasikan Allah yang disembahnya tanpa menyinggung keyakinan orang lain. ${ }^{47}$ Dalam Roma 12:9-10, kepada jemaat di Kota Roma Paulus menekankan untuk menghilangkan kepura-puraan dalam tindakan saling mengasihi dan mendahului dalam memberi hormat.

Rasul Paulus juga menekankan untuk menghormati bagi orang yang membenci dan berbuat jahat dengan mengalahkan kejahatan dengan kebaikan (Roma 12:19-21). Jauh sebelum Paulus menulis kitab Roma, Musa juga menekankan begitu pentingnya untuk menghargai dan menghormati sesama. Hal ini dinyatakan dalam Ulangan 10:1819 yang mengharuskan umat Tuhan untuk menunjukkan kasih kepada orang asing, artinya mereka yang berasal dari luar bangsa Israel. Perintah ini diberikan dengan memperbandingkan kasih Allah yang ditunjukkan-Nya dengan membela dan mengasihi bangsa Israel yang pernah menjadi budak di Mesir.

Untuk itu pendidikan agama Kristen dalam kaitannya dengan pluralisme dan perannya yang penting dalam pengajaran di gereja mengupayakan pendewasaan pada sisi

\footnotetext{
${ }^{47}$ Tafonao, 122.
} 
kerohanian bagi seluruh warga jemaat. Melalui pendidikan tersebut diharap dapat terjadi pengembangan pemahaman yang dapat menyikapi keberagaman. Sehingga orang percaya di manapun bermasyarakat memiliki kemampuan dalam mengelola perbedaan demi tujuan positif dan bermanfaat. Lebih jauh dengan kemampuannya orang percaya dapat berkontribusi dalam pemecahan masalah bagi konflik atau perselisihan akibat keberagaman agama maupun lainnya di Indonesia. ${ }^{48}$ Pendidikan dalam pluralisme agama, yang dikaji dan didasarkan dalam pendidikan agama dapat diarahkan untuk memperteguh keyakinan keagamaan orang percaya baik guru maupun peserta didik, dalam dunia pendidikan saat ini. Namun dapat juga mengembangkan sikap dan rasa empati, simpati dan solidaritas kepada orang lain di sekitarnya. ${ }^{49}$ Yang dapat menimbulkan rasa persaudaraan sebagai sesama anak bangsa yang harus bahu membahu dan bekerja sama membangun negeri tercinta. Dengan sikap menghargai dan dapat menerima kehadiran orang lain dalam perbedaan, setiap orang mampu mengaktualisasi dengan hidup selalu toleran dan mau memberi ruang bagi kebebasan dan kesempatan bagi keyakinan yang berbeda. Dengan demikian harapan bahwa kehidupan anak bangsa ini dapat berkembang secara sehat dan baik dilandasi sikap saling menghargai dan menghormati. ${ }^{50}$

Begitu pentingnya membangun bangsa dalam keberagaman yang saling

\footnotetext{
${ }^{48}$ Sianipar, "Pluralisme Agama Menurut Abraham Kuyper Dan Kontribusinya Bagi Pengembangan Pendidikan Agama Kristen."

49 Saihu, "Pendidikan Pluralisme Agama: Kajian Tentang Integrasi Budaya Dan Agama Dalam Menyelesaikan Konflik Sosial Kontemporer."

50 Moko, "Pluralisme Agama Menurut Nurcholis Madjid (1939-2005) Dalam Konteks Keindonesiaan."
}

menghargai dan menghormati bagi generasi penerus yang akan menjadi tulang punggung bangsa. Pendidikan agama kristen dalam momentum keberagaman ini membawa konsep dan kurikulum yang tetap mempertahankan esensi keselamatan yang mutlak dan sesuai kesepakatan, namun tetap ikut dalam toleransi dan keberagaman di masyarakat pluralisme yang saling menghargai. Pendidikan agama Kristen sebagai dasar dari bermasyarakat dapat memberikan pemahaman kepada para naradidik untuk terus berada dalam kebersamaan dan mau menjaga dan membangun keutuhan bangsa.

\section{Aktualisasi dalam Kemajemukan}

Persoalan dan masalah yang timbul akibat intoleransi adalah suatu keniscayaan dalam bangsa yang majemuk seperti Indonesia. Bahwa kerentanan perpecahan akibat perbedaan keyakinan dapat muncul sewaktu-waktu membutuhkan keterlibatan aktif para pemuka atau pemimpin rohani dari tiaptiap agama. Perlu dibangun kerjasama antar pemuka dalam mengarahkan umat yang dipimpin agar terhindari dari segala kemungkinan timbulnya konflik bahkan berkepanjangan. ${ }^{51}$ Sebab sejatinya Allah menjadikan manusia sebagai ciptaan-Nya yang termulia dengan akal budi yang berbeda dengan ciptaan lainnya. Hal ini ditegaskan pernyataan di Alkitab bahwa Allah merancang manusia dalam citra dan kemuliaan-Nya. Hal itu menekankan istimewanya manusia dihadapan Allah. Manusia menjadi istimewa dibanding ciptaan lainnya karena kelengkapan yang Allah beri agar dapat melakukan mandat Allah. Dari situ dapat dipahami bagaimana eksistensi manusia baik secara

\footnotetext{
51 Objantoro, "Pluralisme Agama-Agama: Tantangan Bagi Teologi Kristen."
} 
individu maupun sosial. Setiap pribadi harus dapat saling menghargai, menolong, menghormati sesama. Hal ini adalah mutlak sebagai bentuk penghargaan terhadap manusia, termasuk dirinya sendiri sepatutnya mendapat sikap dan perlakuan yang baik dari sesama selaku mahluk yang mulia. ${ }^{52}$

Untuk itu orang percaya yang hidup dalam kemajemukan bangsa Indonesia sepatutnya mempunyai rasa peduli yang tinggi terhadap keutuhan bangsa dan juga memiliki sikap bertanggungjawab dalam membangun situasi dan kondisi aman, nyaman dan sentosa baik secara langsung maupun tidak langsung. Sebagai umat percaya harus menyadari tanggung jawab yang diamanatkan Allah dalam hidup bersama sebagai deklarasi imannya. Tuhan Yesus menyatakan bahwa apa dikehendaki seseorang haruslah ia lakukan kepada orang lain (Matius 7:12). Pengajaran ini akan mendorong cara berpikir mengenai eksistensi orang lain berdasarkan diri sendiri. Sehingga, orang percaya tidak hanya berpikir ke dalam diri sendiri namun juga kepada orang lain dengan berkaca pada diri sendiri. Jadi, hal ini akan menjadikan umat Allah menghargai keberadaan orang lain melalui eksistensi dirinya sendiri. ${ }^{53}$ Oleh sebab itu orang percaya dapat membawa perubahan dalam masyarakat dan memberikan impact positif bagi kemajuan bangsa, dengan menegakkan toleransi yang saling menghargai. Apabila sikap menerima dalam perbedaan tidak dikembangkan dan diberlakukan, maka konsekuensi logis yang dapat dialami bangsa Indonesia ialah timbulnya bermacam pertikaian antar penganut masing-masing agama yang

\footnotetext{
52 Objantoro.

${ }^{53}$ Objantoro.
}

akan berujung pada disintegrasi alias perpecahan bangsa. ${ }^{54}$

Sebagai orang percaya tetap mengikuti teladan yang ditunjukkan Yesus dalam dalam bersikap kepada orang atau kelompok marjinal yang tersisihkan oleh mayoritas dan Ia melarang perlakuan diskriminasi dalam masyarakat. ${ }^{55}$ Implementasi bagi orang percaya yang tinggal di tengah-tengah masyarakat majemuk adalah mengaktualisasikan hidupnya sebagai bagian tak terpisahkan dari bangsa dan negara berkebhinekaan sebagai marketplace di mana orang percaya ditempatkan untuk hidup dan berkarya, terlepas dari adat, norma, hukum maupun pandangan dan keyakinan mayoritas di masyarakat. Kesadaran hidup menjadi berkat dalam mengkomunikasikan kebenaran dan menghidupi firman bagi orang percaya idealnya didasari oleh nilai kemanusiaan yang berasal dari kebenaran firman Tuhan tanpa dipengaruhi oleh situasi sosial politik dalam masyarakat. Sebab Kekristenan harus membangun bangsanya dimana ia ditempatkan. ${ }^{56}$

\section{Kesimpulan}

Melihat struktur dari lapisan masyarakat Indonesia, jelas merupakan suatu gambaran kemajemukan yang menunjukkan perbedaan-perbedaan pangkat maupun perbedaan derajat sosial, sehingga hal itu berpotensi sebagai salah satu pemicu konflik horizontal di

\footnotetext{
54 Iqbal, "Pendidikan Multikultural Interreligius: Upaya Menyemai Perdamaian Dalam Heterogenitas Agama Perspektif Indonesia."

${ }^{55}$ Yunus, "Konflik Agama Di Indonesia Problem Dan Solusi Pemecahannya."

56 Elia Tambunan, "Gerakan Transnasional Kristen: Wajah Ekonomi-Politik Agama Dan Pendidikan Di Indonesia," Jurnal Ilmiah Religiosity Entity Humanity (JIREH) 1, no. 1 (2019): 1-17.
} 
masyarakat majemuk. untuk itu peran gereja dan pendidikan dalam agama Kristen membawa paradigma yang benar bagi setiap orang percaya dengan pendampingan dan pengajaran kepada generasi penerus. Sehingga mereka dapat membawa setiap perbuatan dan prilakunya dimasyarakat untuk menjadi berkat dan terang serta berdampak bagi sesama anak bangsa.

Dapat disimpulkan bahwa, pluralisme agama dalam perspektif pendidikan agama Kristen upaya membangun kesatuan Bangsa pertama dimulai dari mengenal dan memahami konsep serta hakikat pluralisme dan seluruh nilai dari kemajemukan. Kedua seluruh orang percaya terlebih guru dan naradidik melihat dan mengerti bahwa pluralisme dalam konsep pendidikan agama Kristen sangat tidak bertentangan dengan apa yang dilakukan oleh kaum maupun organisasi yang mengusung pluralisme namun perlu ditegaskan bahwa pluralisme dalam kesepakatan hanya untuk menjaga dan membangun keutuhan bangsa. Ketiga, dari dasar tersebut maka kekristenan dalam hal ini peran yang dapat dilakukan oleh pendidikan agama Kristen adalah mengaktualisasikan diri dalam hidup bermasyarakat dalam kemajemukan.

\section{Kontribusi Penelitian}

Penulisan ini dapat menjadi landasan dalam meneliti peran pendidikan Kristen yang dikembangkan dalam kurukulum sebagai materi pembelajaran yang dapat menghasilkan generasi yang mencintai Tuhan, sesama dan bangsanya.

\section{Referensi}

Adnan, Gunawan. "Mendefinisikan Ulang Pluralisme Agama Sebagai Sebuah Tantangan Global." Refleksi 13, no.
1 (2011): 35-60.

Arifin, Syamsul. "Kontruksi Wacana Pluralisme Agama Di Indonesia." Jurnal Humanity 5, no. 1 (2009): 11518.

Armayanto, Harda. "Problem Pluralisme Agama." Tsaqafah 10, no. 2 (2014): 325-40.

Azzuhri, Muhandis. "Konsep Multikulturalisme Dan Pluralisme Dalam Pendidikan Agama (Upaya Menguniversalkan Pendidikan Agama Dalam Ranah Keindonesiaan)." In Forum Tarbiyah, 10:13-29, 2012.

Dzakie, Fatonah. "Meluruskan Pemahaman Pluralisme Dan Pluralisme Agama Di Indonesia." AlAdyan: Jurnal Studi Lintas Agama 9, no. 1 (2014): 79-94.

Hadinoto, Nieke Kristiana Atmadja. Dialog Dan Edukasi Keluarga Kristen Dalam Masyarakat Indonesia. Jakarta: BPK Gunung Mulia, 1999.

Iqbal, Mahathir Muhammad. "Pendidikan Multikultural Interreligius: Upaya Menyemai Perdamaian Dalam Heterogenitas Agama Perspektif Indonesia." SOSIO-DIDAKTIKA: Social Science Education Journal 1, no. 1 (2014): 89-98.

Khaerurrozikin, Ahmad. "Problem Sosiologis Pluralisme Agama Di Indonesia." Kalimah: Jurnal Studi Agama Dan Pemikiran Islam 13, no. 1 (2015): 93-114.

M. Legenhausen. Pluralitas Dan Pluralisme Agama. Jakarta: Shadra Press, 2010.

Masduki, Hendri. "Pluralisme Dan Multikulturalisme Dalam Perspektif Kerukunan Antar Umat Beragama (Telaah Dan Urgensinya Dalam 
Sistem Berbangsa Dan Bernegara)." DIMENSI-Journal of Sociology 9, no. 1 (2016): 15-23.

Moko, Catur Widiat. "Pluralisme Agama Menurut Nurcholis Madjid (19392005) Dalam Konteks Keindonesiaan." Medina-Te: Jurnal Studi Islam 13, no. 1 (2017): 61-78. https://doi.org/10.19109/medinate.v1 3i1.1542.

Natalia, Angga. "Faktor-Faktor Penyebab Radikalisme Dalam Beragama (Kajian Sosiologi Terhadap Pluralisme Agama Di Indonesia)." Al-Adyan: Jurnal Studi Lintas Agama 11, no. 1 (2016): 36-56.

Noer, Arafat. "Pluralisme Agama Dalam Konteks Keislaman Di Indonesia." Religi: Jurnal Studi Agama-Agama 15, no. 1 (2019): 51-75.

Objantoro, Enggar. "Pluralisme AgamaAgama: Tantangan Bagi Teologi Kristen." Jurnal Simpson: Jurnal Teologi Dan Pendidikan Agama Kristen 1, no. 1 (2014): 61-80. https://journal.sttsimpson.ac.id/index .php/Js/article/view/6.

Patty, Albertus. "Paradigma Teologia Kristen Terhadap Pluralisme." Situs Komunitas Jemaat - GKI Pondok Indah - Jakarta, 2007. https://gkipi.org/paradigma-teologiakristen-terhadap-pluralisme-agama/.

Rambitan, Stanley R. "Pluralitas Agama Dalam Pandangan Kristen Dan Implikasinya Bagi Pengajaran Pak." Jurnal Shanan 1, no. 1 (2017): 93108.

https://doi.org/10.33541/shanan.v1i1 .1473 .

Saihu, Saihu. "Pendidikan Pluralisme Agama: Kajian Tentang Integrasi Budaya Dan Agama Dalam Menyelesaikan Konflik Sosial Kontemporer." Jurnal Indo-Islamika
9, no. 1 (2019): 67-90.

Schuon, Frithjof. Roots of The Human Condition. Paris, Prancis: World Wisdom Book, 1990.

Setiawan, Andry. "Apologetika Prasuposisional Triperspektivalisme John M. Frame Dan Aplikasinya Terhadap Pemikiran Kristen Pluralis Tentang Pluralisme Agama Di Indonesia." Veritas: Jurnal Teologi Dan Pelayanan 17, no. 1 (2018): 6180.

Sianipar, Desi. "Pluralisme Agama Menurut Abraham Kuyper Dan Kontribusinya Bagi Pengembangan Pendidikan Agama Kristen." Jurnal Shanan Vol.3, no. No.1 (2019): 1057.

http://ejournal.uki.ac.id/index.php/sh an/article/view/1576.

Soesilo, Yushak. "Gereja Dan Pluralisme Di Indonesia," n.d.

Susanti, Aya. "Relevansi Finalitas Kristus Di Tengah-Tengah Arus Pluralisme Dan Pluralitas Masyarakat Indonesia." Evangelikal: Jurnal Teologi Injili Dan Pembinaan Warga Jemaat 1, no. 1 (2017): 85102.

Syafar, Djunawir. "Pluralisme Agama Dalam Pendidikan (Potret Toleransi Beda Agama Di Sd Negeri 46 Hulontalangi Kota Gorontalo)." Jurnal Kajian Islam Interdisipliner 2, no. 2 (2017): 99-115.

Tafonao, Talizaro. Pendidikan Agama Kristen Dalam Masyarakat Majemuk. Yogyakarta: illumiNation Publishing, 2019.

Tambunan, Elia. "Gerakan Transnasional Kristen: Wajah Ekonomi-Politik Agama Dan Pendidikan Di Indonesia." Jurnal Ilmiah Religiosity Entity Humanity (JIREH) 1, no. 1 
(2019): 1-17.

Tambunan, Elia. "Pendidikan Progresif Dan Kaum Urban: Mencari Wajah Baru Kontribusi Sosial.” EDULEAD: Journal of Christian Education and Leadership 1, no. 1 (2020): $56-76$. https://doi.org/10.47530/edulead.v1i 1.27 .

Tumanggor, Raja Oloan. "Misi Dalam Masyarakat Majemuk," 2021.

Umma, Yusuf. "Menangani Masalah Konflik Agama." Jurnal Jaffray 1, no. 1 (2005): 16-24.

Umrati, dan Hengki Wijaya. Analisis Data Kualitatif Teori Konsep Dalam Penelitian Pendidikan. Sulawesi Selatan: Sekolah Tinggi Theologia Jaffray, 2020.

Widjaja, Fransiskus Irwan. "Pluralitas Dan Tantangan Misi: Kerangka Konseptual Untuk Pendidikan Agama Kristen Dalam Masyarakat Majemuk." Regula Fidei 4, no. 1 (2019). https://doi.org/10.33541/jrfvol1iss1p p115.
Yunus, Firdaus M. "Konflik Agama Di Indonesia Problem Dan Solusi Pemecahannya." Substantia: Jurnal Ilmu-Ilmu Ushuluddin 16, no. 2 (2014): 217-28. http://substantiajurnal.org.

Zega, Yunardi Kristian. "Radikalisme Agama Dalam Perspektif Alkitab Dan Implikasinya Bagi Pendidikan Agama Kristen." Jurnal Shanan 4, no. 1 (2020): 1-20. http://ejournal.uki.ac.id/index.php/sh an/article/view/1765.

Zega, Yunardi Kristian. "Jaminan Keselamatan Dalam Injil Yohanes 10: 28-29 Dan Implikasinya Bagi Pengajar Pendidikan Agama Kristen." Jurnal Ilmiah Religiosity Entity Humanity (JIREH) 3, no. 1 (2021): 76-87. 